\title{
DISCUSSION AND REPLY
}

\subsection{7-Ga Magmatism in the South Carpathians: Implications for the Pre-Alpine Basement and Evolution of the Mantle under the European Continent: A Discussion}

\author{
Mihai Ducea \\ California Institute of Technology, Division of Geological and Planetary Sciences, MS100-23, Pasadena, \\ California 91125, U.S.A. \\ (e-mail: ducea@gps.caltech.edu)
}

\section{Introduction}

Drăguşanu and Tanaka (1999) provide intriguing new chemical and isotopic analyses of amphibolites and gneisses from the Cumpăna Group, the oldest lithostratigraphic unit in the Getic-Supragetic unit of the South Carpathians (Balintoni 1975; Pana 1994). Ten amphibolite whole-rock data points form a linear trend in a plot of measured ${ }^{143} \mathrm{Nd} /{ }^{144} \mathrm{Nd}$ against ${ }^{147} \mathrm{Sm} /{ }^{144} \mathrm{Nd}$ (Drăguşanu and Tanaka 1999, fig. 3). Drăguşanu and Tanaka interpreted this as a 1.57-Ga isochron. This age corresponds to the oldest determined magmatism in the south Carpathians and, if true, would be instrumental in elucidating the tectonomagmatic evolution of the Carpathian basement, which is obscured by younger orogenic cycles such as the Hercynian (Variscan) and the Alpine.

The Variscan and Alpine events are consistent with a variety of geologic and thermochronologic data from the Getic-Supragetic unit of the South Carpathians (Dallmeyer et al. 1996). In contrast, no geochronologic evidence is available to support the existence of relics of prior orogenic cycles in this unit. It appears that Precambrian metasedimentary rocks are present in the Getic-Supragetic unit, based on $\mathrm{Nd}$ model ages performed on a variety of metasedimentary basement rocks (D. Pana and P. Erdmer, unpub. data). However, no pre-Hercynian magmatic events have been determined so far in the Getic-Supragetic unit. The Drăguşanu and Tanaka (1999) data are the first to suggest the existence of relics of an older orogen (e.g., an older accreted terrane?) in the Getic-Supragetic realm.

The purpose of this discussion is to explore alternatives to two main conclusions of the Drăgu-

Manuscript received May 11, 1999. şanu and Tanaka (1999) paper. First, their wholerock data may have been originally a mixing line rather than a point and, hence, the inferred age is a potentially inclusive maximum one. Second, the data are equivocal in support of their tectonic interpretation that the Cumpăna metatholeiites represent fragments of an island arc.

\section{Whole-Rock Data: Isochron or Mixing Line?}

The amphibolite Sm-Nd whole-rock data in Drăguşanu and Tanaka (1999, table 1, fig. 3) was interpreted as an isochron reflecting a 1.57-Ga crystallization age. Drăguşanu and Tanaka negate the possibility of two-component mixing, based on lack of mixing relationships between ${ }^{143} \mathrm{Nd} /{ }^{144} \mathrm{Nd}$ (present-day?) and $1 / \mathrm{Nd}$ and indicate a rather small error for the fit $( \pm 85 \mathrm{Ma}, \mathrm{MSWD}=0.47)$. I recalculated the fit of the 10 analyzed amphibolites, using Ludwig's program (1991), and obtained a larger scatter: $1611 \pm 245 \mathrm{Ma}$ and $\mathrm{MSWD}=1.9$. Figure 1 shows that, in detail, the $\epsilon_{\mathrm{Nd}}$ of the 10 amphibolites analyzed by Drăguşanu and Tanaka (1999) does not converge back to a point in $\epsilon_{\mathrm{Nd}}$-time space to better than within $\sim 500$ m.yr. Three amphibolites were also analyzed by the authors for mineral geochronology and yielded Sm-Nd ages of 319-354 Ma. These values are Hercynian and are consistent with all other geochronologic determinations on similar rocks from the South Carpathians (see discussion in Iancu et al. 1998). The scatter around the wholerock isochron age is large enough to cast some doubt on whether this age is meaningful. Clearly, some higher- $\epsilon_{\mathrm{Nd}}$ rocks have younger model ages (fig. 1 , inset). This observation suggests that these am-

[The Journal of Geology, 1999, volume 107, p. 000-000] @ 1999 by The University of Chicago. All rights reserved. 0022-1376/1999/10706-0009\$01.00 


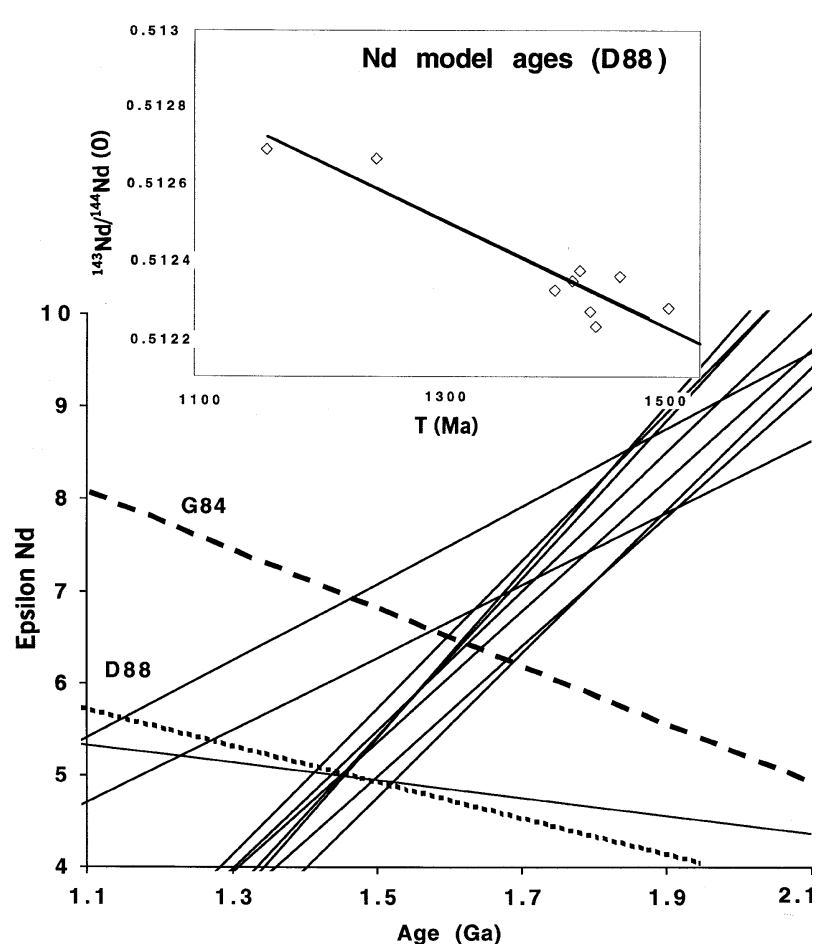

Figure 1. $\epsilon_{\mathrm{Nd}}$ versus age $(\mathrm{Ga})$ diagram for the 10 analyzed amphibolites (solid lines), using the data in table 1 of Drăguşanu and Tanaka (1999). Also shown are depleted mantle evolution curves from DePaolo (1988), dashed line labeled "D88," and Goldstein et al. (1984), dashed line labeled "G84." The model ages calculated using the DePaolo (1988) model (interceptions of the sample lines with the $D 88$ line) are plotted against the measured ${ }^{143} \mathrm{Nd} /{ }^{144} \mathrm{Nd}$ in the Cumpăna amphibolites (inset, upper part of figure).

phiboles either did not form from a uniform reservoir or were contaminated as melts.

An alternative interpretation to the correlation of the whole-rock data of Drăguşanu and Tanaka (1999) is that in part they reflect mixing between two end members: a depleted mantle-like component and the local gneisses as contaminants. Assimilation of continental basement by the Cumpăna metatholeiites was also observed by Drăguşanu et al. (1997) in a major element and trace element study of the same group of rocks. The paragneisses hosting many of the amphibolites (e.g., sample PGM of Drăguşanu and Tanaka 1999) have the required $\mathrm{Nd}$ isotopic compositions to represent contaminants of mantle-derived basaltic melts.

Figure $2 a$ shows a mixing line between the most depleted amphibolite studied by Drăguşanu and Tanaka (1999, sample 48) and sample PGN. The am- phibolites clearly lie near this mixing line. Moreover, the $\mathrm{Nd}$ isotopes correlate well with $\mathrm{Nd}$ concentrations for all but one sample (fig. 2b). The anomalous sample is $\mathrm{S} 6$ and has an unusually high $\mathrm{Sr} / \mathrm{Nd}$ ratio of 135 and low $\mathrm{Nd}$ concentrations (3.74 ppm) compared with all other Cumpăna amphibolites studied by Drăguşanu and Tanaka (1999) and Drăguşanu et al. (1997). That sample aside, the correlation between ${ }^{143} \mathrm{Nd} /{ }^{144} \mathrm{Nd}$ and $1 / \mathrm{Nd}$ is consistent with a mixing hypothesis. I plotted the $\mathrm{Nd}$ isotopes at $330 \mathrm{Ma}$, the minimum age of this inferred mixing. Present-day Nd isotopic ratios display a somewhat poorer correlation with $1 / \mathrm{Nd}$.
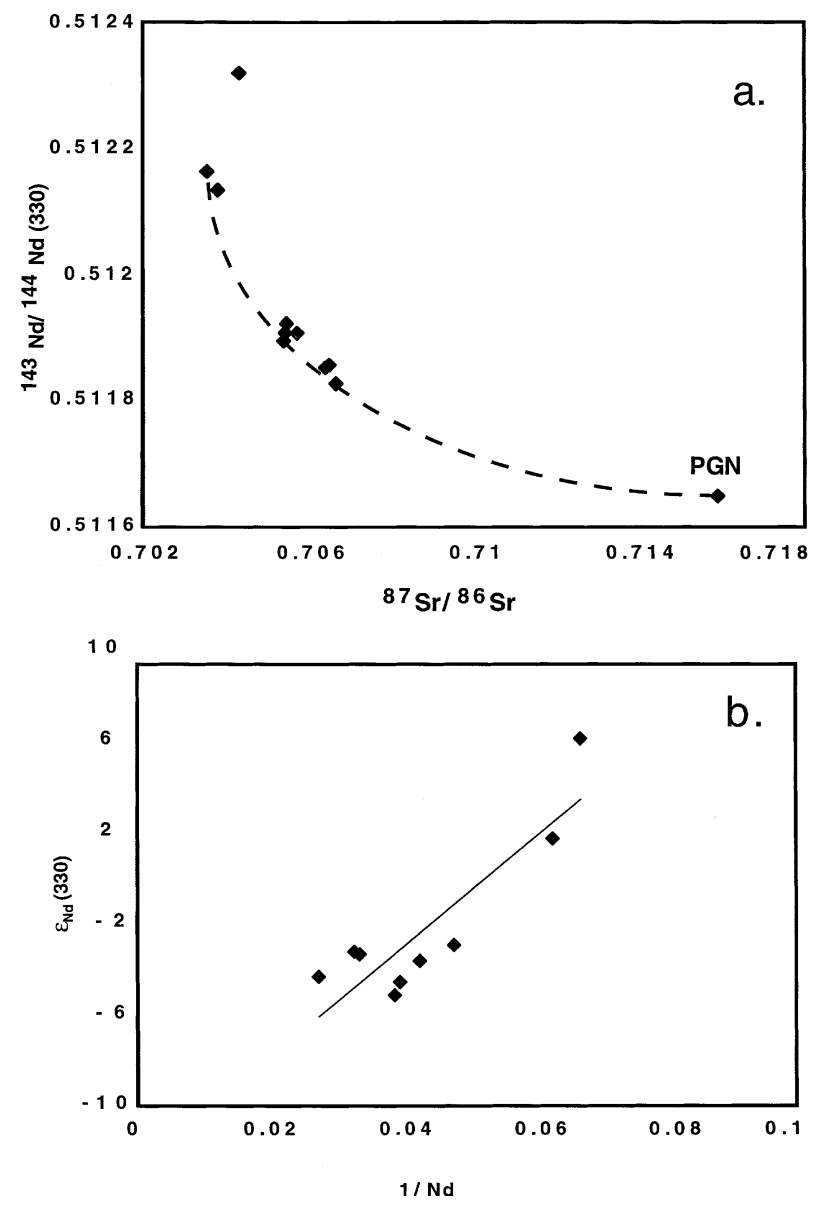

Figure 2. $\quad a,{ }^{87} \mathrm{Sr} /{ }^{86} \mathrm{Sr}\left(\right.$ at $330 \mathrm{Ma}$ ) versus ${ }^{143} \mathrm{Nd} /{ }^{144} \mathrm{Nd}$ (at $330 \mathrm{Ma}$ ) for the 10 amphibolites analyzed by Drăguşanu and Tanaka (1999) and a local metasediment (PGN) also analyzed by them. The amphibolites lie along the calculated mixing curve between a more depleted (perhaps mantle-derived) member and the local metasediments. $b, \epsilon_{\mathrm{Nd}}(330 \mathrm{Ma})$ versus $1 / \mathrm{Nd}$ diagram showing a broad positive correlation $\left(R^{2}=0.783\right)$, which is consistent with a mixing hypothesis. Sample S6 was not used in this regression. 
Based on these observations, I suggest that at least part of the $\mathrm{Nd}$ isotopic heterogeneities measured by Drăguşanu and Tanaka (1999) in the Cumpăna amphibolites are caused by magmatic mixing between mantle and crustal reservoirs.

The crystallization age of these basaltic magmas is constrained to be $\sim 330-1600 \mathrm{Ma}$. The last major mineral equilibration event affecting the Sm-Nd systematics in these rocks took place in the Hercynian ( 320-350 Ma). The slope of the whole-rock amphibolite mixing line in ${ }^{143} \mathrm{Nd} /{ }^{144} \mathrm{Nd}$ versus ${ }^{147} \mathrm{Sm} /{ }^{144} \mathrm{Nd}$ space puts an upper bound for the crustal emplacement of these rocks at $\sim 1600 \mathrm{Ma}$.

Many amphibolite lenses in the Cumpăna Group contain cores of relic gabbros and occasionally eclogitic assemblages. Such unmetamorphosed core gabbros are mentioned in papers on Cumpăna Group rocks (e.g., Udubaşa et al. 1988). Drăguşanu et al. $(1997$, p. 421) mention the presence of such relics. The age of magmatism in the Cumpăna rocks can be constrained by dating these unmetamorphosed gabbros, garnet-bearing gabbros, and/or eclogites. I suggest that the mineral Sm-Nd system could successfully be applied on pyroxenes, plagioclase, amphiboles, and garnet in the unmetamorphosed core assemblages.

\section{Tectonic Interpretations}

Drăguşanu and Tanaka (1999) and Drăguşanu et al. (1997) interpret the Cumpăna amphibolites to be the products of an island arc. However, all field data suggest that the Cumpăna tholeiites intruded in the continental basement represented today by various high-grade gneisses (Dimitrescu et al. 1985). In fact, the Cumpăna unit is characterized by a silicic basement to amphibolites surface area ratio of $\sim 10$. In several outcrops, blocks of paragneisses are preserved within lenses of amphibolites. Drăguşanu et al. (1997) suggested that the chemistry of Cumpăna amphibolites is consistent with various (up to $68 \%$ ) proportions of assimilation of local gneisslike metasedimentary material during magmatic emplacement. A "primitive island arc," as Drăguşanu and Tanaka (1999, p. 237) interpret the Cumpăna am- phibolites, is represented by a succession of mainly mafic rocks formed in an oceanic subduction environment far removed from a continental margin. If the Cumpăna unit represents some form of an island-arc terrane, then the island arc must have been constructed on an older continental crust. The arguments offered by Drăguşanu and Tanaka for an island-arc origin are largely based on the negative anomalies observed among high-field-strength elements such as $\mathrm{Nb}$ and Ta. Given the aforementioned geologic setting, these gabbros could more likely have been intruded near a convergent continental margin, or they may represent extensionrelated underplated mafic material in a region in which the mantle was previously enriched by subduction.

\section{Conclusion}

Further tests need to be aimed at deciphering the age and tectonic setting in which the Cumpăna metatholeiites were formed. An important key to deciding the arc versus nonarc controversy for the basement units in the South Carpathians is to test (e.g., using $\mathrm{Nd}$ provenance studies) whether their metasediments are proximal to a nearby continent, the East European shield, for example, or are exotic. A combination of major element and trace element studies with isotopic studies of the same samples (the amphibolite samples analyzed for isotopes and select trace elements in Drăguşanu and Tanaka 1999 do not appear to be the same as those analyzed for major and trace elements in Drăguşanu et al. 1997), especially the least metamorphosed relics, can yield better quantitative information on the nature of primary magmas, their crustal differentiation, and perhaps the tectonic setting in which they formed.

\section{A C K N O W LE D G M E N T S}

I thank D. Pana for providing his unpublished radiogenic isotopic data and M. Lupulescu (Bucharest University) for insights into the geology of the Făgăraş Group and the South Carpathians in general.

\section{R E FE R E N C E S C I T E D}

Balintoni, I. 1975. Studiul petrogenetic comparativ al unor migmatite din M-tii Făgăraş si Sebes. An. Inst. Geol. Geof. României 44:133-179. In Romanian.

Dallmeyer, R. D.; Neubauer, F.; Handler, R.; Fritz, H.; Muller, W.; Pana, D.; Putis, M. 1996. Tectonothermal evolution of the internal Alps and Carpathians: evi- dence from ${ }^{40} \mathrm{Ar} /{ }^{39} \mathrm{Ar}$ mineral and whole-rock data. Eclogae Geol. Helv. 89:203-227.

DePaolo, D. J. 1988. Neodymium isotope geochemistry: an introduction. Berlin, Springer, $187 \mathrm{p}$.

Dimitrescu, R.; Hann, P. H.; Gheuca, I.; Stefanescu, M.; Srasz, L.; Maruntiu, M.; Serban, E.; and Dumitrascu, 
G. 1985. Geological map of Romania, Cumpăna sheet. Geol. Inst. of Romania, scale $1: 50,000$.

Drăguşanu, C., and Tanaka, T. 1999. 1.57-Ga magmatism in the South Carpathians: implications for the preAlpine basement and evolution of the mantle under the European continent. I. Geol. 107:237-248.

Drăguşanu, C.; Tanaka, T.; and Iwamori, H. 1997. Metamorphosed Precambrian mafic rocks from the south Carpathians: island arc remnants? a geochemical characterization of amphibolites from the Făgăraş Mountains, Romania. Schweiz. Mineral. Petrograph. Mitteilun. 77:419-437.

Goldstein, S. L.; O'Nions, K.; and Hamilton, P. J. 1984. A Sm-Nd isotopic study of atmospheric dust and particulates from major river systems. Earth Planet. Sci. Lett. 70:221-226.
Iancu, V.; Maruntiu, M.; Johan, V.; and Ledru, P. 1998. High-grade metamorphic rocks in the pre-Alpine nappe stack of the Getic-Supragetic basement (Median Dacites, South Carpathians, Romania). Mineral. Petrol. 63:173-198.

Ludwig, K. 1991. ISOPLOT, a plotting and regression program for radiogenic isotope data. U.S. Geol. Surv. Open-File Rept. 91-445.

Pana, D. 1994. Alpine crustal shear zones and pre-Alpine basement terranes in the Romanian Carpathians and Apuseni Mountains. Geology 22:807-810.

Udubaşa, G.; Hărtopanu, I.; Gheucă, I.; and Dinică, I. 1988. The metamorphosed copper-nickel mineralizations from the Vîlsan Valley, Făgăraş Mountains. Dări de Seamă. Inst. Geol. Geofiz. României 72-73: 283-312. 